\title{
Pathogenic and Genetic Diversity of Xanthomonas translucens pv. undulosa in North Dakota
}

\author{
Tika B. Adhikari, Suraj Gurung, Jana M. Hansen, and J. Michael Bonman
}

First, second, and third authors: Department of Plant Pathology, North Dakota State University, Department 7660, P.O. Box 6050, Fargo 58108; and fourth author: United States Department of Agriculture-Agricultural Research Service, Small Grains and Potato Germplasm Research Unit, Aberdeen, ID 83210.

Current address of S. Gurung: Department of Plant Pathology, University of California, Davis, c/o United States Agricultural Research Station, 1636 E. Alisal Street, Salinas, CA 93905.

Accepted for publication 21 December 2011.

\begin{abstract}
Adhikari, T. B., Gurung, S., Hansen, J. M., and Bonman, J. M. 2012. Pathogenic and genetic diversity of Xanthomonas translucens pv. undulosa in North Dakota. Phytopathology 102:390-402.

Bacterial leaf streak (BLS), caused by Xanthomonas translucens pv. undulosa, has become more prevalent recently in North Dakota and neighboring states. From five locations in North Dakota, 226 strains of $X$. translucens pv. undulosa were collected and evaluated for pathogenicity and then selected strains were inoculated on a set of 12 wheat cultivars and other cereal hosts. The genetic diversity of all strains was determined

ential responses to several strains. The $16 \mathrm{~S}$ ribosomal DNA sequences of the strains were identical, and distinct from those of the other Xanthomonas pathovars. Combined rep-PCR and IS-PCR data produced 213 haplotypes. Similar haplotypes were detected in more than one location. Although diversity was greatest $(\approx 92 \%)$ among individuals within a location, statistically significant $(P \leq 0.001$ or 0.05$)$ genetic differentiation among locations was estimated, indicating geographic differentiation between pathogen populations. The results of this study provide information on the pathogen diversity in North Dakota, which will be useful to better identify and characterize resistant germplasm.
\end{abstract} using repetitive sequence-based polymerase chain reaction (rep-PCR) and insertion sequence-based (IS)-PCR. Bacterial strains were pathogenic on wheat and barley but symptom severity was greatest on wheat. Strains varied greatly in aggressiveness, and wheat cultivars also showed differ-
Additional keywords: linkage disequilibrium, resistance, Triticum aestivum, virulence.
Several pathovar names have been used to describe Xanthomonas translucens strains isolated from small grains (17), and earlier researchers have used $X$. translucens pv. translucens in a general sense for any cereal streak pathogen (9). According to the International Society for Plant Pathology list of plant-pathogenic bacteria, $X$. translucens pv. undulosa and $X$. translucens pv. translucens are two pathovars that can mostly induce leaf streak symptoms on wheat and barley (14). Strains pathogenic on both wheat and barley were considered to be $X$. translucens pv. undulosa while strains pathogenic only on barley were proposed as $X$. translucens pv. translucens (11).

Bacterial leaf streak (BLS) or black chaff (53), caused by $X$. translucens pv. undulosa (10), is an important disease of wheat (Triticum aestivum L.) worldwide. Yield losses due to BLS have been reported as high as $40 \%$ from Idaho (22). Crop debris, alternative hosts, and soil appear to be major sources of primary inoculum $(8,30,53,60)$. The bacterium can infect (59) and infest seed (53) and, although a low transmission rate was observed, seed also was considered an important source of primary inoculum (56). The pathogen can disseminate a short distance through dew, rain, and contact between plants (8), and long-distance or intercontinental dissemination can occur through wheat germplasm exchange (35).

\section{Corresponding author: T. B. Adhikari, E-mail address: tadhikari31@yahoo.com}

* The $e$-Xtra logo stands for "electronic extra" and indicates that the online version contains one supplementary table.

http://dx.doi.org/10.1094/PHYTO-07-11-0201

(c) 2012 The American Phytopathological Society
In recent years, BLS epidemics have increased in the Upper Midwest of the United States, particularly in Minnesota, North Dakota, and South Dakota. There are at least three possible reasons for the occurrence of BLS epidemics in this region. First, winter wheat production in this region has increased recently and fall-sown wheat could be more prone to BLS infection and, thus, serve as a potential source of inoculum for spring wheat. Secondly, there has been increased planting of wheat cultivars moderately resistant to Fusarium head blight such as 'Alsen' and 'Steel-ND' (38), which are susceptible to $X$. translucens pv. undulosa. Finally, humid and mild weather conditions during late growth stages of winter wheat may favor infection and dissemination of inoculum into the adjacent spring wheat fields.

Understanding of the genetic diversity of bacterial plant pathogens is a key component for successful disease resistance breeding and deployment of host plant resistance (31). X. translucens pv. undulosa is one of the pathovars of $X$. translucens, with each pathovar being distinguished based on compatibility to various cereal host plants $(15,37)$. Among many potential cereal hosts, $X$. translucens pv. undulosa has been described infecting wheat, barley, oat, rye, and triticale $(10,11)$. Pathogenic variation in 81 strains of $X$. translucens pv. undulosa from North and South America was analyzed by inoculating a set of 19 differential wheat cultivars (39). Although the strains were highly variable, no significant interactions between the wheat cultivars and the bacterial strains were observed (39). In the past, the main research conducted on BLS has focused on evaluating wheat germplasm for resistance to $X$. translucens pv. undulosa $(2,18,35,40,55)$. Three wheat cultivars ('Pavon', 'Mochis', and 'Angostura') (18, 35 ) and several winter wheat accessions (2) were identified as potential sources of resistance to $X$. translucens pv. undulosa. 
In the past decades, the genetic diversity within pathovars (e.g., cerealis, hordei, secalis, translucens, and undulosa) of $X$. translucens has been assessed using polyclonal and monoclonal antibodies, neutral molecular markers, membrane proteins, fatty acid profiling, and ribosomal intergenic sequences $(11,12,44$, $47,49,54,61$ ). Kolliker et al. (27) found a significant effect of geographic location on genetic diversity of $X$. translucens pv. graminis using amplified fragment length polymorphism (AFLP) markers. Repetitive sequence-based polymerase chain reaction (rep-PCR) genomic fingerprint profiles supported by pathogenicity assays revealed that the 33 strains from ornamental asparagus and all $X$. translucens reference strains discriminated $X$. translucens into pathovars arrhenatheri, graminis, phlei, and phleipratensis, and enabled identification of $X$. translucens pv. undulosa and X. translucens pv. translucens groups $(10,49)$. Importantly, all strains isolated from ornamental asparagus belonged to $X$. translucens pv. undulosa (49). Although X. translucens pv. undulosa causes extensive damage to wheat in North Dakota and neighboring states each year, little is known about the pathogenic and genetic diversity of the pathogen.

Investigating the genetic structure of plant pathogens may provide a better understanding in order to develop geographically targeted management strategies (31). Our goal was to investigate the pathogenic and genetic diversity of $X$. translucens pv. un- dulosa strains associated with the recent BLS outbreaks of wheat in North Dakota and subsequently formulate strategies to manage this reemerging pathogen. The specific objectives of this study were to (i) evaluate pathogenic variation among strains of $X$. translucens pv. undulosa on wheat cultivars and other cereal host plants, (ii) investigate the genetic diversity of $X$. translucens pv. undulosa strains from five locations in North Dakota using repPCR and insertion sequence-based (IS)-PCR techniques, and (iii) compare the genetic relationships of selected strains of $X$. translucens pv. undulosa from wheat with other reference strains and pathovars of Xanthomonas using 16S ribosomal DNA (16S rDNA) sequence analysis.

\section{MATERIALS AND METHODS}

Collection of BLS-infected leaf samples. Field surveys were conducted in major wheat-producing locations in North Dakota during the 2008 and 2009 seasons (Fig. 1; Table 1). A random sampling strategy was used to collect severely BLS-infected flag leaf samples from each site. The sampling sites surveyed were in fields at each of five locations. Within a field, samples were collected in a W-shaped pattern. Distances between sample collections in a field varied according to the severity and distribution of BLS. Leaf samples were collected from different

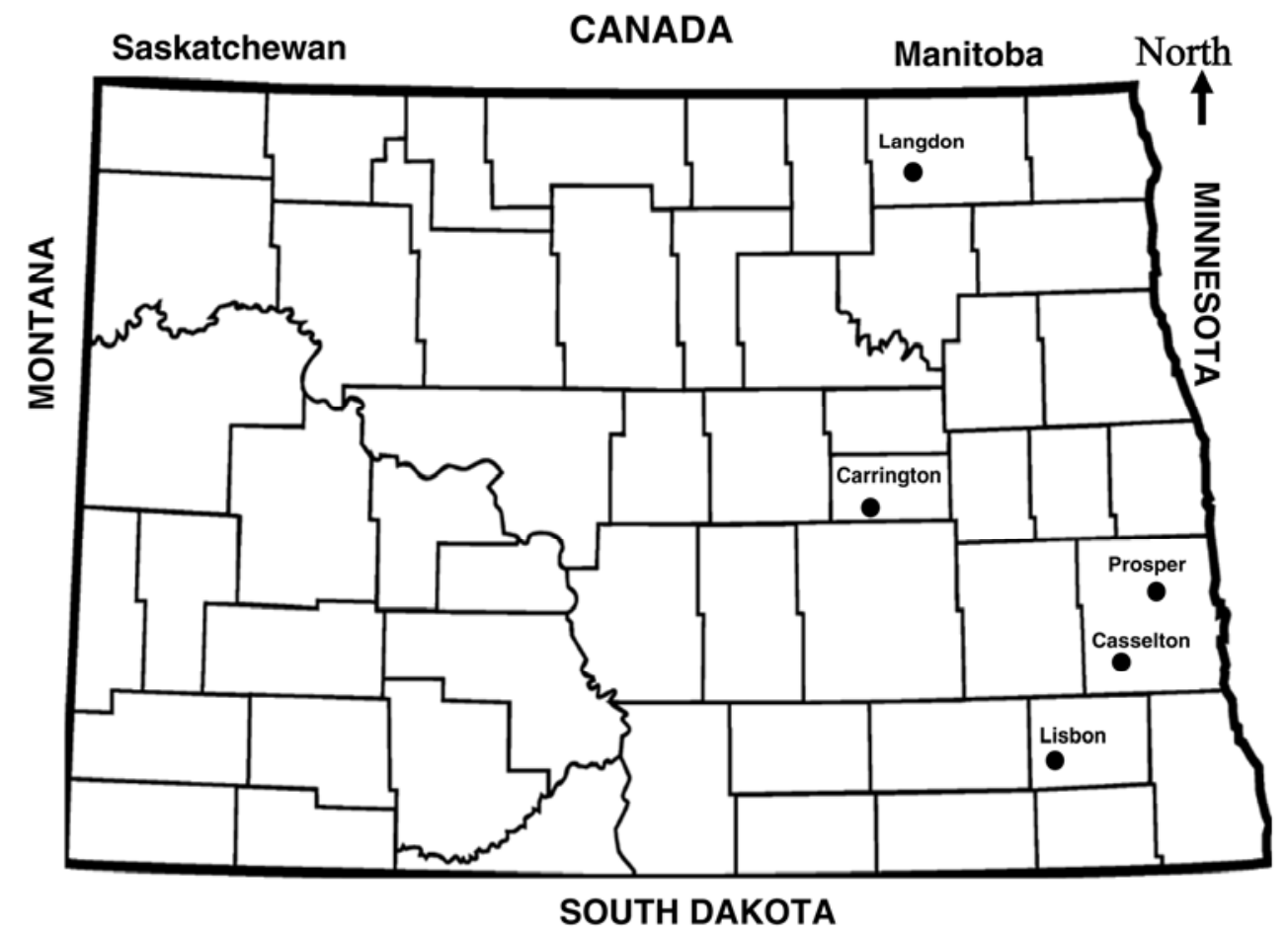

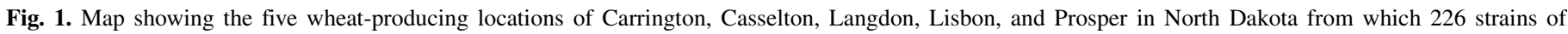
Xanthomonas translucens pv. undulosa were collected in 2008 and 2009.

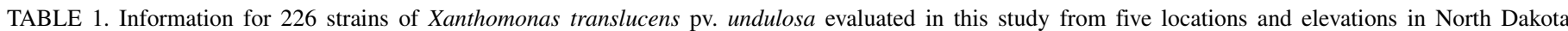
collected during the 2008 and 2009 seasons

\begin{tabular}{|c|c|c|c|c|c|}
\hline Location & Coordinates, elevation ${ }^{\mathrm{a}}$ & $\begin{array}{c}\text { Number of } \\
\text { fields sampled }\end{array}$ & Year & Wheat type ${ }^{b}$ & Wheat cultivar planted ${ }^{\mathrm{c}}$ \\
\hline Carrington & $47^{\circ} 27^{\prime} \mathrm{N}, 99^{\circ} 7^{\prime} \mathrm{W}$, and $464 \mathrm{~m}$ & 10 & 2009 & HRSW & Alsen and breeding lines \\
\hline Casselton & $46^{\circ} 54^{\prime} \mathrm{N}, 97^{\circ} 12^{\prime} \mathrm{W}$, and $282 \mathrm{~m}$ & 8 & 2008 and 2009 & HRSW and HRWW & Alsen, Parshall, Jerry and breeding lines \\
\hline Lisbon & $46^{\circ} 26^{\prime} \mathrm{N}, 97^{\circ} 41^{\prime} \mathrm{W}$, and $332 \mathrm{~m}$ & 6 & 2009 & HRWW & Jerry and breeding lines \\
\hline Langdon & $48^{\circ} 76^{\prime} \mathrm{N}, 98^{\circ} 37^{\prime} \mathrm{W}$, and $492 \mathrm{~m}$ & 12 & 2009 & HRSW and Durum & Breeding lines \\
\hline Prosper & $46^{\circ} 97^{\prime} \mathrm{N}, 97^{\circ} 02^{\prime} \mathrm{W}$, and $273 \mathrm{~m}$ & 14 & 2009 & HRSW & Alsen, Granite and breeding lined \\
\hline
\end{tabular}

a Information on each of the locations represented by latitude, longitude, and elevation in meters above sea level, respectively.

${ }^{\mathrm{b}}$ HRSW = hard red spring wheat and HRWW = hard red winter wheat.

c Cultivars from which strains of $X$. translucens pv. undulosa were collected. 
hard red winter wheat, hard red spring wheat, durum, and advanced breeding lines (Table 1). At least three to five leaves were collected from each cultivar or line within a site to represent a sample.

Sixteen sites were surveyed in fall 2009 in Langdon, and most of the sites showed severe symptoms of BLS (Fig. 1). Leaf samples were collected from hard red spring wheat and durum cultivars and breeding lines planted at the farm of the Langdon Research Extension Center. Distances between the sites were 0.5 to $2 \mathrm{~km}$. The other four collection locations were Casselton, Carrington, Lisbon, and Prosper (Fig. 1; Table 1). In all, 8 to 12 sites in Casselton were sampled in late spring 2008 and fall 2009, respectively. Leaf samples were collected within a 3-km sampling area and most of the samples were collected from commercial hard red spring wheat 'Alsen' and 'Parshall' and hard red winter wheat 'Jerry'. Some leaf samples also were collected from promising wheat varieties and elite lines, and barley lines planted at the demonstration plots and varietal testing trials at Agronomy Seed Farm, Casselton. Ten adjacent or nearby fields were sampled from Carrington in fall 2009. These sampling sites were within $5 \mathrm{~km}$. In Lisbon, six sites were sampled within $3 \mathrm{~km}$ in early summer 2009 and samples were mainly collected from hard red winter wheat cultivars and breeding lines. Fourteen sites were surveyed in Prosper in fall 2009. Samples were collected from the experimental farm and farmers' fields within $10 \mathrm{~km}$. Leaf samples were placed in an envelope and labeled with date of collection, location, and cultivar or line and brought to the laboratory at the Department of Plant Pathology, North Dakota State University, Fargo. The leaf samples were held at $20^{\circ} \mathrm{C}$ until bacterial isolations were made.

Isolation and maintenance of bacteria. Bacteria were isolated from the advancing lesion associated with bacterial exudates. The leaves were cut into 2- to 4-mm segments from each sample (three samples per site), and three leaf segments were placed in $100 \mu \mathrm{l}$ of sterile distilled water in a small test tube for $10 \mathrm{~min}$, allowing bacterial ooze to disperse into water. One wire-loop of bacterial suspension of each strain was streaked on Wilbrink's medium (50) and incubated at room temperature for 5 days. To determine morphological characteristics, a single representative colony of each strain was selected and restreaked on peptone sucrose agar (PSA) plates (48) and incubated at room temperature for 3 days. In all, 226 putative strains of $X$. translucens pv. undulosa from wheat and 4 strains from barley from Casselton were obtained. A pure culture of each strain was stored in $30 \%$ glycerol at $-80^{\circ} \mathrm{C}$ and these frozen bacterial cultures served as sources of bacteria for subsequent experiments.

Pathogenicity, biochemical, and physiological tests. All putative 226 strains of $X$. translucens pv. undulosa from Carrington $(n=36)$, Casselton $(n=23)$, Langdon $(n=63)$, Lisbon $(n=$ $50)$, and Prosper $(n=54)$ were tested for pathogenicity on flag leaves of hard red spring wheat line 'ND495' and barley (Hordeum vulgare subsp. vulgare) 'Robust'. Three seeds were planted in a plastic cone $(3.8 \mathrm{~cm}$ in diameter and $20 \mathrm{~cm}$ long) (Stuewe and Sons, Inc., Tangent, OR) filled with Fison sunshine mix number 1 (Fison Horticulture, Vancouver, BC, Canada). Nine plants (three plants/cone and three replications) were inoculated with each strain. Plants were maintained in the greenhouse and watered and fertilized as needed. The bacterial strains were revived on PSA and incubated at $28^{\circ} \mathrm{C}$ for $72 \mathrm{~h}$. Bacterial cells were scraped with a wire-loop, and inoculum was prepared by suspending cells in $20 \mathrm{ml}$ of sterile deionized water per plate. Before inoculation, inoculum was adjusted to an optical density of 0.2 at $590 \mathrm{~nm}$ using a spectrophotometer, which was approximately equivalent to $1 \times 10^{7} \mathrm{CFU} / \mathrm{ml}$ based on dilution plating after inoculation. For each isolate, the flag leaf was infiltrated with $\approx 100 \mu$ of inoculum using a disposable syringe without a needle, as described previously $(2,40)$. Leaves infiltrated with water and known reference strains (LMG 885 and LMG 886) of X. translucens pv. undulosa served as negative and positive controls, respectively. Plants were moved into a growth chamber at 21 and $18^{\circ} \mathrm{C}$ day and night temperature, respectively, with a 16-h photoperiod. Disease reactions within the infiltrated areas of 0.2 to $0.4 \mathrm{~cm}^{2}$ were recorded between 7 and 10 days after infiltration using a 0-to-6 scale $(2,39)$, where $0=$ no visible symptoms, $1=$ chlorosis without water-soaked lesions, $2=<10 \%$ water soaking, $3=10$ to $30 \%$ water soaking, $4=31$ to $70 \%$ water soaking, $5=71$ to $100 \%$ water soaking, and $6=$ water soaking extending beyond the infiltrated area (55). Disease reactions were calculated based on the average of nine infiltrated areas on flag leaves (one site on each flag leaf). Median disease scores $\leq 2$ were classified as resistant and those $>2$ were classified as susceptible. To characterize strains based on disease reactions on wheat cultivars and other cereal host plants, we used the term "aggressiveness", which referred to the quantitative component of pathogenicity.

Strains of $X$. translucens pv. undulosa used for biochemical and physiological tests were recovered from stock cultures by streaking on PSA medium. Major bacteriological characteristics (51) were determined for a set of 29 strains of $X$. translucens pv. undulosa from five geographical locations (Carrington, $n=6$; Casselton, $n=6$; Langdon, $n=6$; Lisbon, $n=5$, and Prosper, $n=6$ ) and some strains were also tested for their pathogenic variability (Table 2). These tests were gram reaction, oxidation and fermentative metabolism, gelatin hydrolysis, oxidase reaction, catalase reaction, starch hydrolysis, and growth on 1 and 5\% sodium chloride.

Pathogenic variation of $X$. translucens pv. undulosa strains on wheat cultivars. Twelve wheat cultivars with different levels of resistance to BLS ('Alsen', 'Dam', 'Fil', 'Magnum', 'Mochis', 'ND495', 'Pavon', plant introduction '[PI] 266860', 'PI 345476', 'PI 326301', 'PI 338387', and 'PI 351315') were selected based on previous studies $(2,18,35,40,55)$. The spring wheat breeding line 'ND495' was used as susceptible check. Because of limited seed of the wheat cultivars, we were able to evaluate a subset of 29 strains of $X$. translucens pv. undulosa from five locations (six strains of each location except Lisbon) in this study (Table 2). Our initial pathogenicity tests showed that these 29 strains were highly aggressive on wheat line 'ND495'. In addition, these strains were used for pathogenic variation experiments (Table 2) and were the same strains used for biochemical and physiological tests. Planting wheat cultivars, inoculum preparation, inoculation, and greenhouse conditions were the same as described previously (2). Briefly, the experiment was conducted using a randomized complete block design (RCBD) with three replications. Two separate experiments were conducted for each strain in a greenhouse. Three plants grown in each cone were considered as the experimental unit. For each strain, 18 plants (three plants/cone, three replications, and two experiments) were inoculated. The replications were regarded as random effect while wheat cultivars were considered to be a fixed effect.

Inoculum of each strain was adjusted to $1 \times 10^{7} \mathrm{CFU} / \mathrm{ml}$ as described above and infiltrated on the adaxial surface of a fully expanded flag leaf using a disposable syringe without a needle (40). Disease reactions on wheat cultivars were assessed on only one infiltrated leaf area, as described above. Median disease scores were calculated from ordinal data using a nonparametric analysis $(13,52)$ and used to characterize aggressiveness of the strains on a set of the 12 wheat cultivars (Table 2). In our previous study (2), median disease scores of $\leq 2$ (i.e., $<10 \%$ water soaking and chlorosis symptoms on the flag leaf) was a reliable criterion to differentiate resistant and susceptible wheat germplasm. Thus, median disease scores of 0 to 6 were used to generate the strain differences on a set of the 12 wheat cultivars based on aggressiveness in this study.

Comparison of aggressiveness of $X$. translucens pv. undulosa strains on cereal hosts. To further evaluate pathogenicity of $X$. translucens pv. undulosa on different cereal host plants, six highly aggressive strains (BLS-CS40, BLS-CS41, BLS-CS42, 
BLS-CS43, BLS-CS48, and BLS-CS49) from wheat and four strains (BLS-CS54, BLS-CS55, BLS-CS56, and BLS-CS57) from barley in Casselton, ND were selected and tested on hard red spring wheat line 'ND495', barley 'Robust', oat (Avena sativa L.) 'Ajay', rye (Secale cereale) 'Ac Remington', and triticale 'PI 634537'. In this study, strains from wheat are referred to "wheat strains" and strains from barley are designated as "barley strains". Plants were arranged in an RCBD with three replications. The experiment was repeated twice in a greenhouse as described previously (2). Each treatment consisted of three plants per replication. Each cone was considered an experimental unit, and the flag leaf of each plant was regarded as a sampling unit. Disease reactions were assessed between 7 and 10 days after infiltration, as described above.

Phenotypic data analysis. Nonparametric analysis $(13,52)$ was performed using the PROC MIXED procedure of SAS (version 9.2; SAS Institute Inc., Cary, NC). Median disease scores, relative treatment effects, and their confidence intervals at $95 \%$ level were estimated to compare aggressiveness of each strain on a set of 12 wheat cultivars and five cereal hosts, and determine significant interactions $(P \leq 0.001)$ between bacterial strains and wheat cultivars.
DNA extraction. Genomic DNA of each strain was extracted as described previously (29) and dissolved in $1 \times$ Tris-EDTA buffer (10 mM Tris- $\mathrm{HCl}$ and $1 \mathrm{mM}$ EDTA, $\mathrm{pH}$ 8.0). DNA quality of each sample was checked using a spectrophotometer (NanoDrop 1000; Thermo Scientific Inc., Wilmington, DE). DNA concentration $(25 \mathrm{ng} / \mathrm{ml})$ was prepared for each strain from the stock DNA and stored at $-20^{\circ} \mathrm{C}$.

Selection of PCR techniques. In previous studies, both repPCR $(3,6,33,49,57)$ and IS-PCR (3) techniques were documented as reliable molecular tools to investigate population biology and genetic structure of plant-pathogenic bacteria. These improved techniques for monitoring genomic diversity in large populations of bacteria not only were simpler, faster, and cheaper than the other molecular techniques but also were useful to detect spatial distribution of pathogen haplotypes in the fields and to measure a high of level diversity $(3,57)$. During the course of this study, the fully sequenced genome of $X$. translucens pv. undulosa was not available. Therefore, we chose to use rep-PCR and IS-PCR techniques to evaluate the genomic variation among the 226 strains.

Standardization of PCR techniques. All reagents were purchased from the Promega Corporation (Madison, WI) and primers were synthesized by Integrated DNA Technologies Inc.

TABLE 2. Pathogenic diversity of 29 strains of Xanthomonas translucens pv. undulosa from five locations in North Dakota evaluated on a set of 12 wheat cultivars $^{\mathrm{a}}$

$$
\text { Score }^{\mathrm{d}}
$$

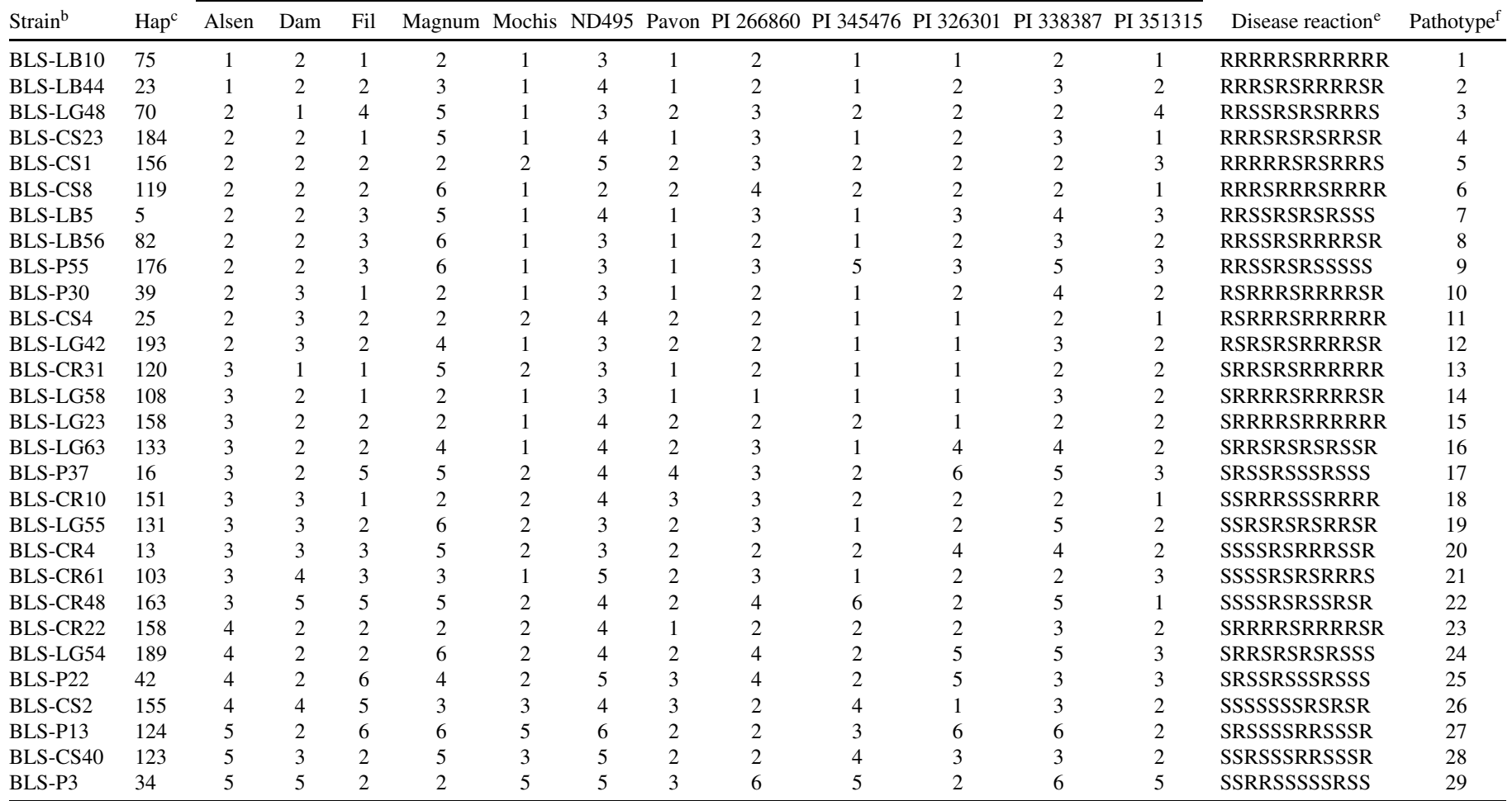

${ }^{a}$ Wheat cultivars were arranged in randomized complete block design. Two experiments were conducted in the greenhouse. In each experiment, there were three replications. Disease scores of the nine infiltrated areas on flag leaves (one site on each flag leaf) were averaged. Each plastic cone was considered as a replication and contained three plants.

b Twenty-nine strains of $X$. translucens pv. undulosa isolated from wheat in Carrington, Casselton, Lisbon, Langdon, and Prosper in North Dakota were analyzed on 12 wheat cultivars. The naming for $X$. translucens pv. undulosa strains from North Dakota is as follows: BLS = bacterial leaf streak, which is followed by the location from where the strains were collected: $\mathrm{CR}=$ Carrington, $\mathrm{CS}=$ Casselton, $\mathrm{LB}=$ Lisbon, $\mathrm{LG}=$ Langdon, and $\mathrm{P}=\mathrm{Prosper}$.

${ }^{\mathrm{c}}$ Haplotypes were identified based on the combined data of insertion sequence-based polymerase chain reaction (PCR) and repetitive sequence-based PCR techniques.

${ }^{\mathrm{d}}$ Disease scores within the filtrated areas on the flag leaves were visually estimated in plants between 7 and 10 days after infiltration. The size of the infiltrated areas was 0.2 to $0.4 \mathrm{~cm}^{2}$ and a disease rating scale of 0 to $6(39,55)$ was used, where $0=$ no visible symptoms, $1=$ chlorosis without water-soaked lesions, $2=$ $<10 \%$ water soaking, $3=10$ to $30 \%$ water soaking, $4=31$ to $70 \%$ water soaking, $5=71$ to $100 \%$ water soaking, and $6=$ water soaking extending beyond the infiltrated area. A nonparametric analysis $(13,52)$ was used to calculate median disease scores from ordinal data and used to characterize aggressiveness of strains in each wheat cultivar tested. For example, median values of 1 indicate strains are least aggressive while median values of 4 or more indicate strains highly aggressive on a particular wheat cultivar.

${ }^{\mathrm{e}} \mathrm{R}=$ resistant and $\mathrm{S}=$ susceptible. Disease reactions corresponded with the 12 wheat cultivars tested.

f Pathotypes were classified based on disease reactions on 12 wheat cultivars. 
(Coralville, IA). Initially, concentrations of all primer sets used in both rep-PCR and IS-PCR techniques were confirmed using genomic DNA of the sequenced strain BLS-CS42 (formerly BLSW16 strain from Casselton, ND) of $X$. translucens pv. undulos $a$ and reference strains. Primers and water without template DNA served as negative controls. To determine consistency to confirm banding patterns and generate haplotype patterns, both rep-PCR and IS-PCR amplifications with genomic DNA from randomly selected strains from five populations were done three times. Prior to conducting actual experiments, a series of preliminary PCRs were run to confirm and standardize PCR conditions, annealing temperatures, number of cycles, quality and quantity of template DNA, and concentration of enzyme and other reagents used in the reactions. Electrophoretic mobility of fragments in each lane was checked visually and compared with identical fragments in neighboring lanes. In addition, the rep-PCR and IS-PCR fingerprint patterns (referred to as the patterns of DNA fragments) among strains of $X$. translucens pv. undulosa were compared visually with the 1-kb ladder used as a size marker (Invitrogen Corporation, Carlsbad, CA). To evaluate reproducibility of weak or faint bands revealed by each primer set, two separate gels were run in different times. If confirmed, only polymorphic bands were included in data analysis.

rep-PCR analysis. Primers ERIC1R and ERIC2 (for enterobacterial repetitive intergenic consensus [ERIC]-PCR) and BOXA1R (for BOX elements [BOX]-PCR) were used $(16,59)$ for all strains. All rep-PCR cycles and conditions were as described previously $(3,33)$, with some modifications. For ERIC primers, each $25-\mu \mathrm{l}$ total volume of mixture contained $4 \mu \mathrm{l}$ of genomic DNA $(25 \mathrm{ng} / \mathrm{ml}), 8.6 \mu \mathrm{l}$ of sterile distilled water, $2.5 \mu \mathrm{l}$ of dimethyl sulfoxide (DMSO), $0.4 \mu$ l of bovine serum albumin ( $\mathrm{pH} 8.8$ ), $5 \mu \mathrm{l}$ of Gitschier buffer, $4 \mu \mathrm{l}$ of $2 \mu \mathrm{M}$ primer mixture, and $0.5 \mu \mathrm{l}$ of Taq DNA polymerase. For the BOX primer, each $25-\mu \mathrm{l}$ total volume of mixture contained $4 \mu \mathrm{l}$ of genomic DNA (25 ng/ $\mu \mathrm{l}), 13.6 \mu \mathrm{l}$ of sterile distilled water, $2.5 \mu \mathrm{l}$ of DMSO, $0.4 \mu \mathrm{l}$ of bovine serum albumin $(\mathrm{pH} 8.8), 2 \mu \mathrm{l}$ of $5 \times$ reaction buffer stock solution $(83 \mathrm{mM}$ ammonium sulfate $[8.0 \mathrm{pH}$ ], $335 \mathrm{mM}$ Tris- $\mathrm{HCl}, 33.5 \mathrm{mM}$ magnesium chloride, $33.5 \mu \mathrm{M}$ EDTA, and $150 \mathrm{mM} \beta$-mercaptoethanol), $2 \mu \mathrm{l}$ of $2 \mu \mathrm{M}$ primer, and $0.5 \mu \mathrm{l}$ of Taq DNA polymerase. Each rep-PCR was carried out in a PTC100 Peltier Thermal cycler (MJ Research, Inc., Waterman, MA) programmed for $7 \mathrm{~min}$ at $95^{\circ} \mathrm{C}$ for initial denaturation; 35 cycles consisting of $1 \mathrm{~min}$ at $94^{\circ} \mathrm{C}, 1 \mathrm{~min}$ at $52^{\circ} \mathrm{C}$ for annealing, and a 1-min extension at $65^{\circ} \mathrm{C}$; with a final extension cycle at $65^{\circ} \mathrm{C}$ for $8 \mathrm{~min}$ followed by $20 \mathrm{~h}$ at $4^{\circ} \mathrm{C}$ for incubation.

IS-PCR-analysis. In a previous study, the IS-PCR primer J3 amplified sequences from several pathovars of Xanthomonas $(3,4)$. Thus, the J3 primer was selected for use in this study. All PCR cycles and conditions for the J3 primer were as described previously (4), with minor modifications. Each $25-\mu$ l total volume of mixture contained $4 \mu \mathrm{l}$ of genomic DNA $(25 \mathrm{ng} / \mu \mathrm{l}), 13.6 \mu \mathrm{l}$ of sterile distilled water, $2.5 \mu \mathrm{l}$ of DMSO, $0.4 \mu \mathrm{l}$ of bovine serum albumin $(\mathrm{pH} 8.8), 2 \mu \mathrm{l}$ of $5 \times$ reaction buffer stock solution (83 mM ammonium sulfate [pH 8.0], $335 \mathrm{mM}$ Tris- $\mathrm{HCl}, 33.5 \mathrm{mM}$ magnesium chloride, $33.5 \mu \mathrm{M}$ EDTA, and $150 \mathrm{mM} \beta$-mercaptoethanol), $2 \mu \mathrm{l}$ of $2 \mu \mathrm{M}$ primer, and $0.5 \mu \mathrm{l}$ of Taq DNA polymerase. Each reaction was carried out in PTC-100 Peltier Thermal cycler (MJ Research, Inc.) programmed for $7 \mathrm{~min}$ at $95^{\circ} \mathrm{C}$ for initial denaturation; 30 cycles consisting of $1 \mathrm{~min}$ at $94^{\circ} \mathrm{C}, 3 \mathrm{~min}$ at $68^{\circ} \mathrm{C}$ for annealing, and a 3 -min extension at $68^{\circ} \mathrm{C}$; with a final extension cycle at $65^{\circ} \mathrm{C}$ for $15 \mathrm{~min}$ followed by $20 \mathrm{~h}$ at $4^{\circ} \mathrm{C}$ for incubation.

Gel electrophoresis for rep-PCR and IS-PCR products. Approximately, $15 \mu \mathrm{l}$ of each PCR product was separated in $1 \%$ agarose gel in $0.5 \times$ Tris-borate-EDTA (TBE) buffer $(0.089 \mathrm{M}$ Tris-borate, $0.089 \mathrm{M}$ boric acid, and 0.002 M EDTA). Electrophoresis of gels was conducted for $12 \mathrm{~h}$ at $115 \mathrm{~V}$ and stained with ethidium bromide for $15 \mathrm{~min}$. The stained gel was photographed in a Fluorochem 2200 Image system, (Alpha Innotech Corp., San Leandro, CA).

Fingerprinting data analysis. To determine the genetic diversity of $X$. translucens pv. undulosa, the strains were grouped into five populations according to the location of the collection. These locations and strains were Carrington $(n=36)$, Casselton $(n=$ $23)$, Langdon $(n=63)$, Lisbon $(n=50)$, and Prosper $(n=54)$. Fingerprints for each strain were first obtained individually using $\mathrm{BOX}, \mathrm{ERIC}$, and $\mathrm{J} 3$ primers alone and then grouped according to unique DNA banding patterns. Both rep-PCR and IS-PCR techniques were used for all strains. For each PCR technique, representative strains of each haplotype were added in the same agarose gel to confirm band positions. The combined rep-PCR and IS-PCR data were used to identify putative haplotypes and the results were repeated to confirm the proposed haplotypes. Binary data were prepared in Microsoft Office Excel (version 2007) based on 1 for presence and 0 for absence of the amplified band. The molecular sizes for DNA bands for each strain were formatted in the GENALEX 6 (46). Haplotypes were constructed for each strain. Strains with the same haplotypes were considered clones. All of the analyses were done after clone correction. The software POPGENE version 1.32 was used to estimate the total number of alleles, gene diversity $(H)$, and genetic distance $(D)$ for each population or location (62). Genetic diversity across locations within each location was estimated using the Nei's unbiased gene diversity (43). Multilocus linkage disequilibrium $(L D)$ was assessed using the index of association $\left(\bar{r}_{d}\right)$ parameter. The $\bar{r}_{d}$ value for each location was estimated with the program MULTILOCUS version 1.3 (5). A corrected standardized fixation index $\left(G_{\text {ST }}^{\prime \prime}\right)$ was calculated to estimate the pairwise measures of genetic differentiation of $X$. translucens pv. undulosa populations using GenoDive 2.0 Beta version software $(24,36)$. Analysis of molecular variance (AMOVA), which partitions genetic variation within and among populations or locations, was performed using the Arlequin 3.1 software $(19,20)$. Variance components and $F_{\text {ST }}$ values were tested by 1,000 permutations of haplotypes among strains to obtain significance levels (19).

$16 S$ rDNA sequence analysis. To determine genetic relationships among strains from wheat with the other pathovars or strains of Xanthomonas, 35 strains representing the X. translucens pv. undulosa population from the five locations in North Dakota were selected to represent $\approx 15 \%$ of the total collection. These strains were chosen for $16 \mathrm{~S}$ rDNA sequence analysis because they were highly aggressive and genetically highly diverse based on the results of pathogenicity tests and rep-PCR and IS-PCR techniques. $X$. translucens pathovar reference strains or DNA kindly provided by Dr. David J. Norman, University of Florida, United States and Dr. Claude Bragard, Unité de phytopathologie, Université catholique de Louvain, Louvain-la-Neuve, Belgium were included and sequenced. These strains were $X$. translucens pv. poae American Type Culture Collection (ATCC) 33804, X. translucens pv. undulosa LMG 8282, Xanthomonas sp. X1553, X. translucens pv. arrhenatheri ATCC 33803, X. translucens pv. cerealis LMG 7393, X. translucens pv. translucens 1 LMG 5263+1, X. translucens pv. translucens 2 ATCC 10771, and X. translucens pv. hordei LMG 8281.

Genomic DNA of each strain was amplified with the $27 \mathrm{~F}\left(5^{\prime}-\right.$ AGAGTTTGATCATGGCTCAG-3') and 1378R (5'-CGGTGT GTACAAGGCCCGGGAACG-3') primers $(25,27)$. Each reaction (total volume: $25 \mu \mathrm{l}$ ) contained $13 \mu \mathrm{l}$ of sterile deionized water, $1 \mu \mathrm{l}$ of genomic DNA $(25 \mathrm{ng} / \mu \mathrm{l}), 4 \mu \mathrm{l}$ of $5 \times \mathrm{Taq}$ polymerase buffer, $2 \mu \mathrm{l}$ of $25 \mathrm{mM} \mathrm{MgCl} 2,0.5 \mu \mathrm{l}$ of $10 \mathrm{mM}$ dNTP mix, $2 \mu \mathrm{l}$ of $4 \mu \mathrm{M}$ each $27 \mathrm{~F}$ and $1378 \mathrm{R}$ primer, and $0.5 \mu \mathrm{l}$ of Taq polymerase ( 5 units/ $\mu \mathrm{l}$ ). Each PCR was carried out in a PTC-100 Peltier Thermal cycler (MJ Research, Inc.) programmed for $15 \mathrm{~min}$ at $95^{\circ} \mathrm{C}$ for initial denaturation; 30 cycles consisting of $30 \mathrm{~s}$ at $95^{\circ} \mathrm{C}$, $60 \mathrm{~s}$ at $48^{\circ} \mathrm{C}$, and $2 \mathrm{~min}$ at $72^{\circ} \mathrm{C}$; followed by a final 5 -min extension at $72^{\circ} \mathrm{C}$. The amplified PCR products $(\approx 5 \mu \mathrm{l})$ were run 
in $2 \%(\mathrm{wt} / \mathrm{vol})$ agarose gel (Sigma-Aldrich, Inc., St. Louis) in $0.5 \times$ TBE buffer (0.089 M Tris-borate, $0.089 \mathrm{M}$ boric acid, and 0.002 M EDTA) for PCR confirmation. After confirmation, the remaining amplified PCR products were shipped to the Molecular Cloning Laboratories (MCLAB, San Francisco) for sequencing of the 16S rDNA region in both sense and anti-sense directions.

The 16S rDNA sequences of $X$. translucens pv. undulosa strains derived in this study were compared with the 16S rDNA sequences of the other closely related pathovars and type strains of Xanthomonas spp., as described previously by Hauben et al. (23). The 16S rDNA sequences of the Xanthomonas spp. were downloaded from GenBank (http://www.ncbi.nlm.nih.gov/ BLAST). According to Hauben et al. (23), the Xanthomonas type strain EMBL accession numbers were as follows: $X$. populi $\mathrm{LMG}$ 5743 (X95922), X. fragariae LMG 708 (X95920), X. hortorum pv. hederae LMG 733 (Y10759), X. arboricola pv. juglandis LMG 747 (Y10757), X. cassavae LMG 673 (Y10762), X. codiaei LMG 8678 (Y10765), X. bromi LMG 947 (Y10764), X. cucurbitae LMG 690 (Y10760), X. axonopodis pv. axomopodis LMG 538 (X95919), X. oryzae pv. oryzae LMG 5047 (X95921), X. vasicola pv. holcicola LMG 736 (Y10755), X. pisi LMG 847 (Y10758), X. melonis LMG 8670 (Y10756), X. translucens pv. translucens LMG 876 (X99299), X. sacchari LMG 471 (Y10766), and X. albilineans LMG 494 (X95918).

The 16S rDNA sequences of 35 strains of $X$. translucens pv. undulosa from North Dakota (accession numbers JN869465 to JN869509), X. translucens pathovar reference strains, and Xanthomonas type strains downloaded from GenBank (http://www. ncbi.nlm.nih.gov/BLAST) were compiled first in FASTA format and then aligned using the ClustalX (V1.83) program. Each aligned sequence was trimmed at the same length, which was an $\approx 1.11-\mathrm{kb}$ fragment. The trimmed sequences were realigned and the final alignment was converted to MEGA format for analysis. A neighbor-joining tree was constructed with the software MEGA4 that uses pairwise comparisons of 16S rDNA sequences of all of the tested Xanthomonas strains. Analysis of reliability was subjected to a bootstrap test with 1,000 replicates.

\section{RESULTS}

Pathogenicity, biochemical, and physiological tests. Generally, $X$. translucens pv. undulosa induced compatible reactions on both wheat and barley, whereas $X$. translucens $\mathrm{pv}$. translucens induced compatible reactions only on barley $(10,11)$. In this study, the induction of water-soaked lesions was considered a compatible reaction for the wheat- $X$. translucens pv. undulosa interaction. All 226 strains of $X$. translucens pv. undulosa were pathogenic on wheat line 'ND495' and barley 'Robust' (Fig. 2) and were able to develop small water-soaked, chlorotic lesions at the infiltrated sites after infiltration. Symptoms induced by the strains were similar to those produced by $X$. translucens pv. undulosa reference strains (LMG 885 and LMG 886). Leaves infiltrated with sterile distilled water did not produce any symptom on flag leaves of barley and wheat. In general, wheat strains were more aggressive than barley strains (Fig. 2).

All 29 strains tested formed round, bright yellow colonies on PSA and were gram negative. The strains were strict aerobes, oxidase negative, catalase positive, and did not hydrolyze starch. A few strains liquefied gelatin and grew on $1 \%$ sodium chloride but none of the tested strains grew on $5 \%$ sodium chloride (data not shown).

Pathogenic variation among strains of $X$. translucens pv. undulosa. Bacterial strains varied greatly in aggressiveness on the 12 wheat cultivars. All strains were highly aggressive on the susceptible wheat line 'ND495'. In contrast, $\approx 10 \%$ of the strains tested were aggressive on 'Mochis' wheat (Table 2). Analysis of variance from nonparametric analysis revealed significant differences among wheat cultivars $(\mathrm{df}=11, F$ value $=116.1)$ and among bacterial strains $(\mathrm{df}=28, F$ value $=31.36)$ (data not shown). In addition, interactions between wheat cultivars and bacterial strains $(\mathrm{df}=308, F$ value $=15.19)$ were highly significant $(P<$ 0.001 ), suggesting that race specificity may exist in $X$. translucens pv. undulosa. Among 29 strains evaluated, each strain was represented by a single pathotype (Table 1). Four strains among them-BLS-CS2 (pathotype 26 and haplotype 155), BLS-P13 (pathotype 27 and haplotype 124), BLS-CS40 (pathotype 28 and haplotype 123), and BLS-P3 (pathotype 29 and haplotype 34)were more aggressive on the wheat cultivars than the other strains tested (Table 2).

Six wheat strains induced symptoms on both wheat and barley (Table 3). Four barley strains also were aggressive on wheat but these strains were less aggressive than wheat strains (Table 3). For example, two wheat strains (BLS-CS42 and BLS-CS43) were nonpathogenic on rye and oat (median disease score $=0$ ) whereas one wheat strain (BLS-CS40) and one barley strain (BLS-CS57) were more aggressive on triticale (median disease score $=3$ ). The remaining strains did not cause symptoms on triticale (Table 3 ).

Analysis of genetic diversity $(\boldsymbol{H})$. In total, 47 polymorphic DNA patterns were generated by ERIC (15 bands), BOX (20 bands), and J3 (12 bands) primers (Fig. 3). The combined rep-PCR and IS-PCR techniques were used for the 226 strains and resulted in 213 distinct haplotypes (Supplementary Table 1). Some haplotypes contained two strains and were detected from a single location. For examples, haplotype 67 (BLS-CR28 and BLSCR33), haplotype 27 (BLS-CR17 and BLS-CR18), and haplotype 152 (BLS-CR5 and BLS-CR12) from Carrington; haplotype 202 (BLS-P31 and BLS-P48), haplotype 39 (BLS-P30 and BLS-P49), haplotype 100 (BLS-P9 and BLS-P11), and haplotype 172 (BLSP15 and BLS-P26) from Prosper; haplotype 185 (BLS-LB1 and BLS-LB12) and haplotype 36 (BLS-LB24 and BLS-LB29) from Lisbon; and haplotype 164 (BLS-LG47 and BLS-LG49) from Langdon each had two strains. Similar haplotypes were found in more than one location. For examples, haplotype 206 (BLS-LG22 and BLS-P52) was found in both the Langdon and Prosper populations. Haplotype 15 (BLS-CR15 and BLS-LB38) was found in both Carrington and Lisbon. Similarly, haplotype 158 (BLS-CR22 and BLS-LG23) also was detected in Carrington and Langdon populations. In total, 13 strains appeared to be clones and were excluded from data analysis. The Prosper population had the highest $H(0.24)$ while the Langdon population had the lowest (0.19) (Table 4). Overall, $H$ values for five populations ranged from 0.19 to 0.24 (Table 4).

Gametic disequilibrium. $L D$, measured by $\bar{r}_{d}$ values, was 0.017 to 0.054 and differed significantly $(P \leq 0.001)$ from zero (Table 4). The Carrington population had the highest $\bar{r}_{d}(0.054)$ while the Lisbon population had the lowest (0.017) (Table 4).

Population differentiation $\left(G_{\text {ST }}^{\prime \prime}\right)$ and genetic distance $(D)$. The $G^{\prime \prime}$ 'sт values for pairwise comparisons five populations were 0.014 to 0.218 (Table 5). The highest $G^{\prime \prime}$ ST value $(0.218)$ was found between Carrington and Langdon populations, which also was significant $(P \leq 0.001)$. However, the lowest $G^{\prime \prime}{ }_{\text {ST }}$ value (0.01) was observed between the Carrington and Prosper populations (Table 5). The $G_{\text {ST }}^{\prime \prime}$ values between the Carrington and Casselton populations, Carrington and Lisbon populations, Casselton and Lisbon populations, Lisbon and Langdon populations, and Langdon and Prosper populations were significant only at $P \leq$ 0.05. $G_{\text {sT }}^{\prime \prime}$ values between the Carrington and Prosper populations, Casselton and Langdon populations, Casselton and Prosper populations, and Lisbon and Prosper populations were not significant (Table 5).

$D$ values calculated between pairwise comparisons among five populations were 0.01 to 0.14 (Table 5). The highest $D(0.14)$ was detected between the Lisbon and Casselton populations and Langdon and Carrington populations. In contrast, the lowest $D$ (0.01) was observed between the Casselton and Carrington populations (Table 5). AMOVA revealed low $(\approx 8 \%)$ genetic differen- 
tiation among locations while the majority of the genetic variation $(\approx 92 \%)$ occurred within locations (Table 6). In addition, significant genetic differentiation $\left(F_{\mathrm{ST}}=0.095, P \leq 0.001\right)$ also occurred within and among populations (Table 6 ).

16S rDNA sequence analysis. The mean level of sequence similarity among these strains was $99.5 \%$. Similarly, the other seven pathovars of $X$. translucens had exactly the same sequence similarity. When the 35 strains from North Dakota were compared with the 16 pathovars of Xanthomonas, the mean level of sequence similarity was $99.4 \%$. In addition, the highest nucleotide difference was observed in X. fragariae (LMG 708), with a 26nucleotide difference (data not shown). The dendrogram generated from the neighbor-joining clustering method showed two clusters for all of the tested Xanthomonas spp. One cluster had all strains of $X$. translucens pv. undulosa from North Dakota and reference strains of $X$. translucens pathovars while the other cluster contained different pathovars of Xanthomonas analyzed (Fig. 4). The sequence similarity within cluster 1 was between 99.5 and $100 \%$ and the nucleotide difference was 0 to 1 (data not shown). The sequence similarities within cluster 2 were 97.9 to $99.9 \%$ and the nucleotide difference was 1 to 26 (data not shown).

\section{DISCUSSION}

The pathogenic and genetic diversity of $X$. translucens pv. undulosa strains associated with recent BLS outbreaks in North Dakota were analyzed with pathogenicity, standard bacteriological tests, aggressive profiles on different wheat cultivars and cereal host plants, 16S rDNA sequences analysis, and rep-PCR and IS-PCR techniques. These results suggested that $X$. translucens pv. undulosa populations examined in this study are
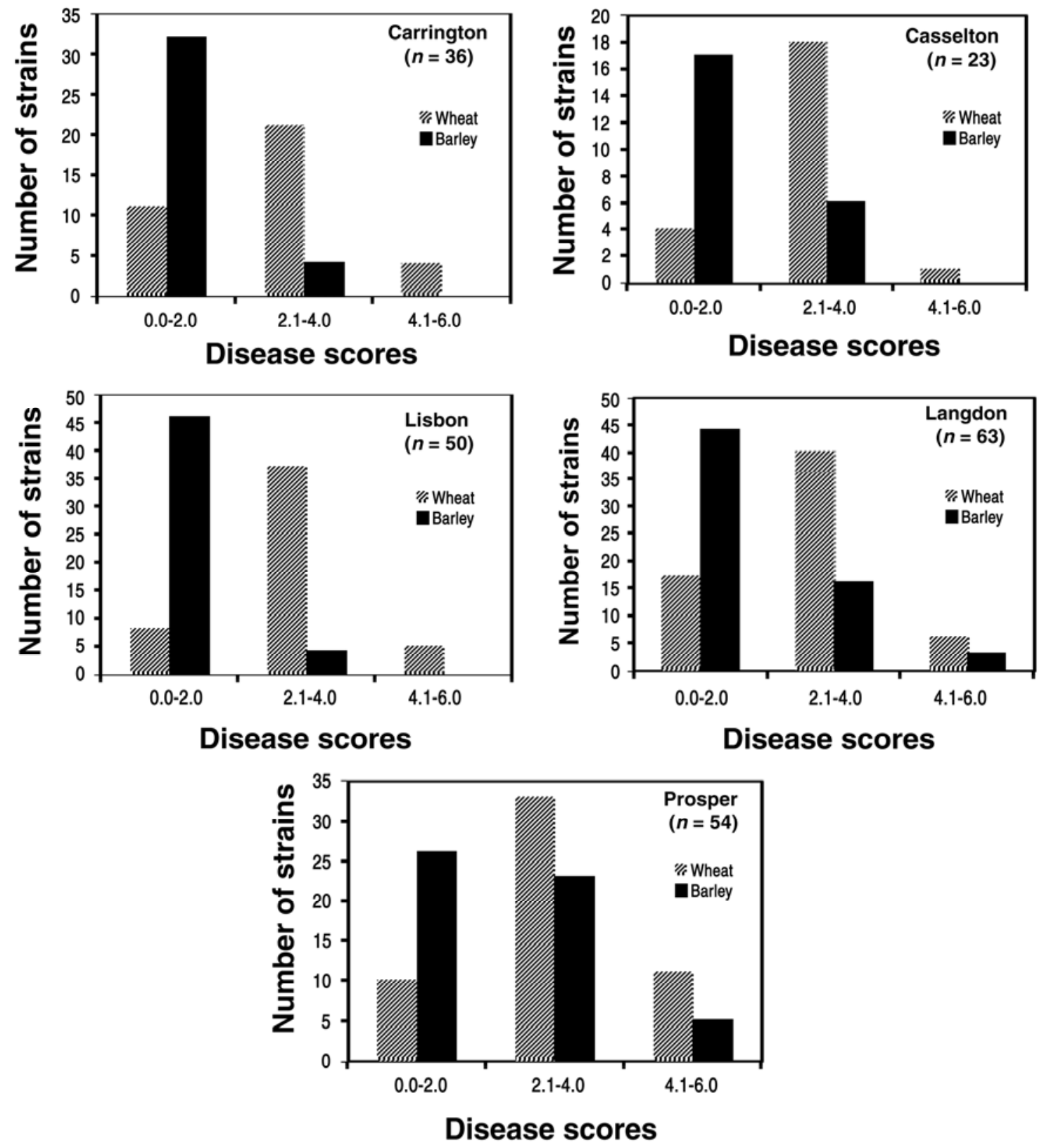

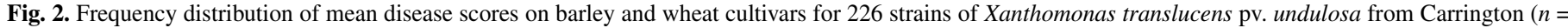

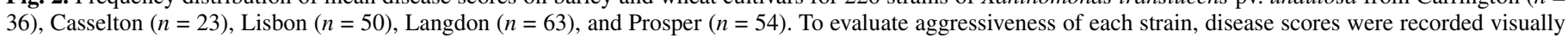

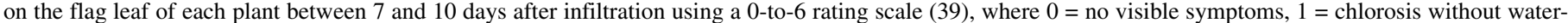

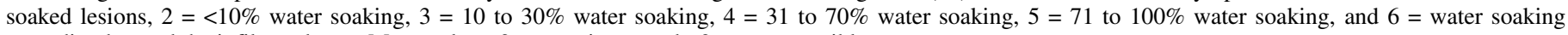
extending beyond the infiltrated area. Mean value $\leq 2$ was resistant and $>2$ was susceptible. 
composed of pathologically and genetically diverse strains. In the previous studies, the genetically diverse strains within a pathovar of Xanthomonas were identified by several conventional and molecular techniques $(6,7,11,12,28,29,33,34,45,49)$. Our results also indicate that $X$. translucens pv. undulosa strains are capable of infecting different cereal host plants such as wheat, barley, and triticale. The finding that a high level of pathogenic and genetic variation exists in $X$. translucens pv. undulosa in North Dakota may provide a basis for selecting strains that are useful for identifying and characterizing new resistance genes in wheat. To our knowledge, this is the first study to demonstrate a high genetic diversity of $X$. translucens pv. undulosa from wheat in the United States using genotyping techniques targeting dispersed elements in the bacterial genomes.

TABLE 3. Nonparametric analysis criteria such as median disease scores, relative treatment effects $\left(p_{i j}\right)$, and $95 \%$ confidence intervals $(\mathrm{CI})$ relative treatment effects $\left(p_{i j}\right)$ were calculated from ordinal data and used to characterize aggressiveness of 10 randomly selected strains of Xanthomonas translucens pv. undulosa on barley, oat, rye, triticale, and wheat

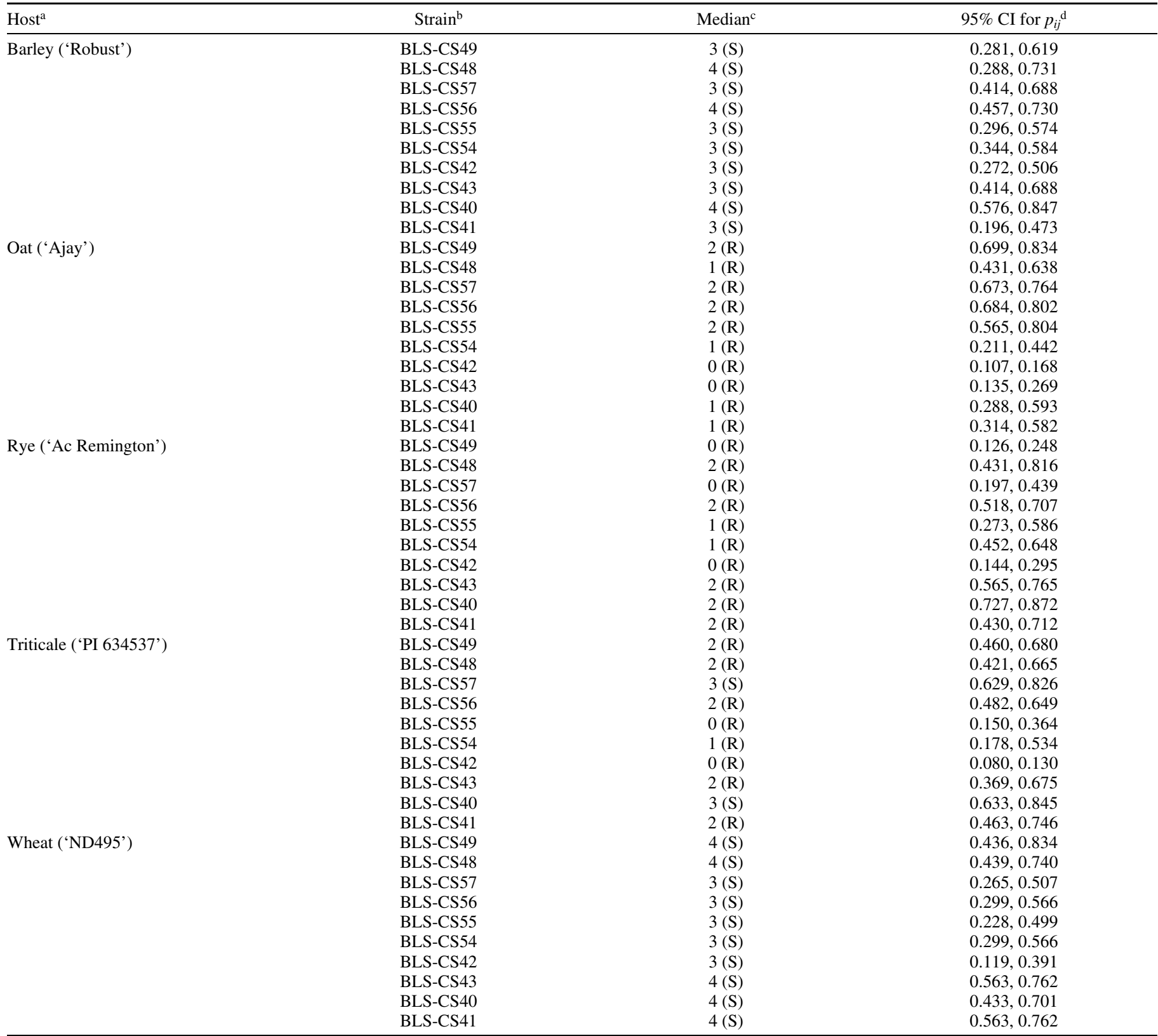

a Two experiments were conducted in the greenhouse. In each experiment, disease scores of the nine infiltrated areas on flag leaves (one site on each flag leaf) were averaged. Cereal host plants were arranged in randomized complete block design with three replications. Each cone was considered as replication and contained three plants.

b Bacterial strains were collected from barley and wheat in Casselton in North Dakota were tested. These included BLS-CS49 (durum wheat), BLS-CS48 (spring wheat), BLS-CS57 (barley), BLS-CS56 (barley), BLS-CS55 (barley), BLS-CS54 (barley), BLS-CS42 (spring wheat), BLS-CS43 (spring wheat breeding line1032), BLS-CS40 (spring wheat), and BLS-CS41 (spring wheat breeding line 313).

${ }^{\mathrm{c}}$ Disease scores were recorded visually on the flag leaf of each plant between 7 and 10 days after infiltration on an ordinal 0 -to- 6 rating scale $(39)$, where $0=$ no visible symptoms, $1=$ chlorosis without water-soaked lesions, $2=<10 \%$ water soaking, $3=10$ to $30 \%$ water soaking, $4=31$ to $70 \%$ water soaking, $5=71$ to $100 \%$ water soaking, and $6=$ water soaking extending beyond the infiltrated area. A nonparametric analysis $(13,52)$ was used to calculate median disease scores from ordinal data and used to characterize aggressiveness of strains in each wheat cultivar tested. For example, median value 1 indicates strains are least aggressive while median disease score 4 refers to strains are highly aggressive on a particular wheat cultivar. Median, $p_{i j}$ and $\mathrm{CI}$ values were estimated $(13,52,55)$. Median value $\leq 2$ was resistant and $>2$ was susceptible. Letter in parenthesis after median value represent $\mathrm{R}=$ resistant and $\mathrm{S}=$ susceptible reaction.

${ }^{\mathrm{d}}$ First and second values in the parentheses indicate lower limit and upper limit at $95 \%$ CI, respectively (13). 
Inoculation of the 226 strains confirmed that these strains were able to infect a wheat cultivar similar to infection by $X$. translucens pv. undulosa reference strains (LMG 885 and LMG 886). This finding was further supported by the observation that the 10 randomly selected strains of $X$. translucens pv. undulosa were able to cause disease symptoms on wheat and barley but their aggressiveness varied according to the cereal host plants tested. For example, strains BLS-CS42 and BLS-CS43 were nonpathogenic on rye and oat; however, two strains, BLS-CS40 and BLS-CS47, were more aggressive on triticale. Although pathogenicity tests support the hypothesis that $X$. translucens pv. undulosa might infect other cereal hosts in addition to wheat and barley, the relatively few samples evaluated in this study were not adequate to draw definite conclusions as to whether or not $X$. translucens pv. undulosa has broad host range. Testing additional strains is necessary to fully understand the pathogenic diversity of $X$. translucens pv. undulosa on different host plants.

Little previous research has examined the pathogenic variability of $X$. translucens pv. undulosa. Although variations in aggressiveness among strains from various geographic areas differed on
TABLE 4. Genetic diversity of Xanthomonas translucens pv. undulosa populations from five locations in North Dakota revealed by the combined data on repetitive sequence-based polymerase chain reaction (PCR) with the BOX and enterobacterial repetitive intergenic consensus primers and an insertion sequence-based PCR with the $\mathrm{J} 3$ primer

\begin{tabular}{lcccc}
\hline Population & $\begin{array}{c}\text { Sample } \\
\text { size }\end{array}$ & $\begin{array}{c}\text { Clone-corrected } \\
\text { data }\end{array}$ & $\begin{array}{c}\text { Gene } \\
\text { diversity }\end{array}$ & $\bar{r}_{\mathrm{d}} \mathrm{b}$ \\
\hline Carrington & 36 & 32 & 0.22 & $0.054^{* *}$ \\
Casselton & 23 & 23 & 0.21 & $0.065^{* *}$ \\
Langdon & 63 & 60 & 0.19 & $0.047^{* *}$ \\
Lisbon & 50 & 48 & 0.20 & $0.017^{*}$ \\
Prosper & 54 & 50 & 0.24 & $0.028^{* *}$ \\
Total & 226 & 213 & $\ldots$ & $\ldots$ \\
\hline
\end{tabular}

${ }^{\text {a }}$ Gene diversity $(42,43)$ within locations was calculated from clone-corrected data.

b The standardized index of association $\left(\bar{r}_{\mathrm{d}}\right)$ statistics were estimated for each population (5). The significance of $\bar{r}_{\mathrm{d}}$ was tested with 1,000 randomizations of the data by comparing the observed value to that expected under the null hypothesis of $\bar{r}_{\mathrm{d}}=0$. The null hypothesis of multilocus linkage disequilibrium was rejected if $P<0.001$ or 0.05 ; ** indicates significant at $P=0.001$.
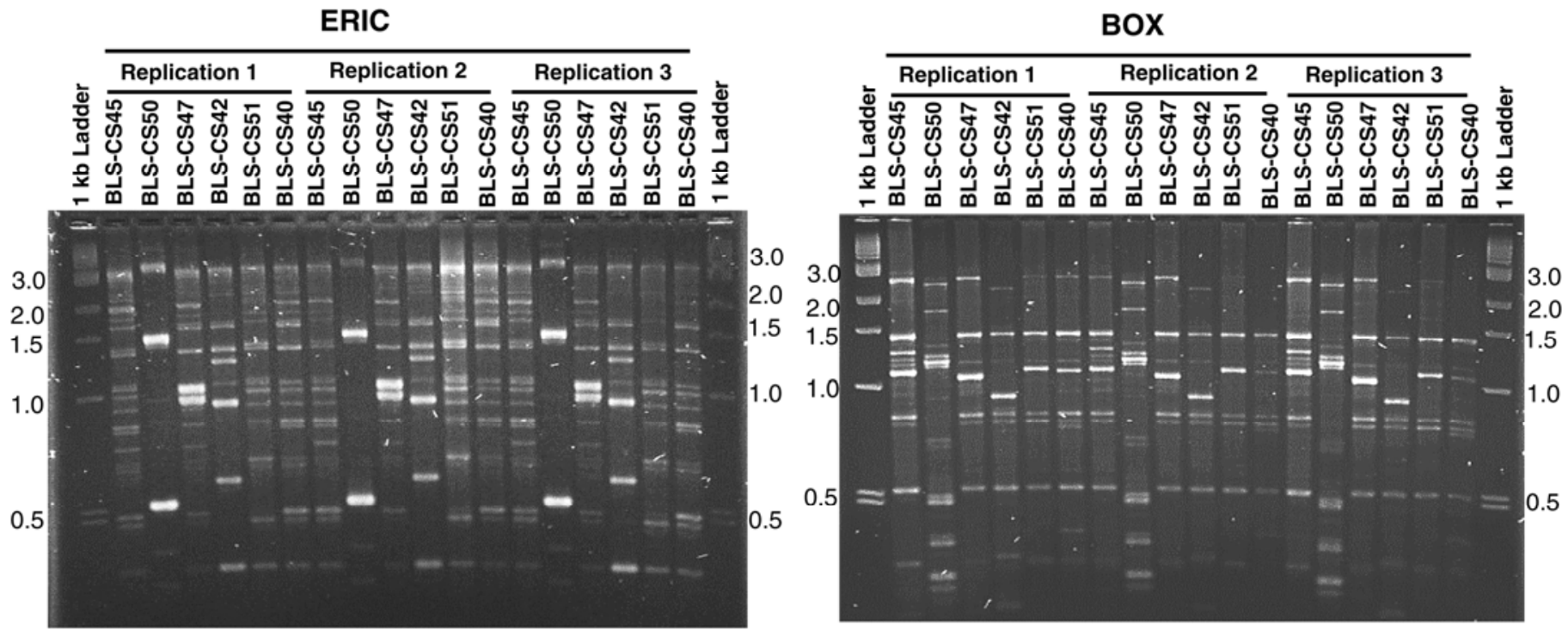

J3

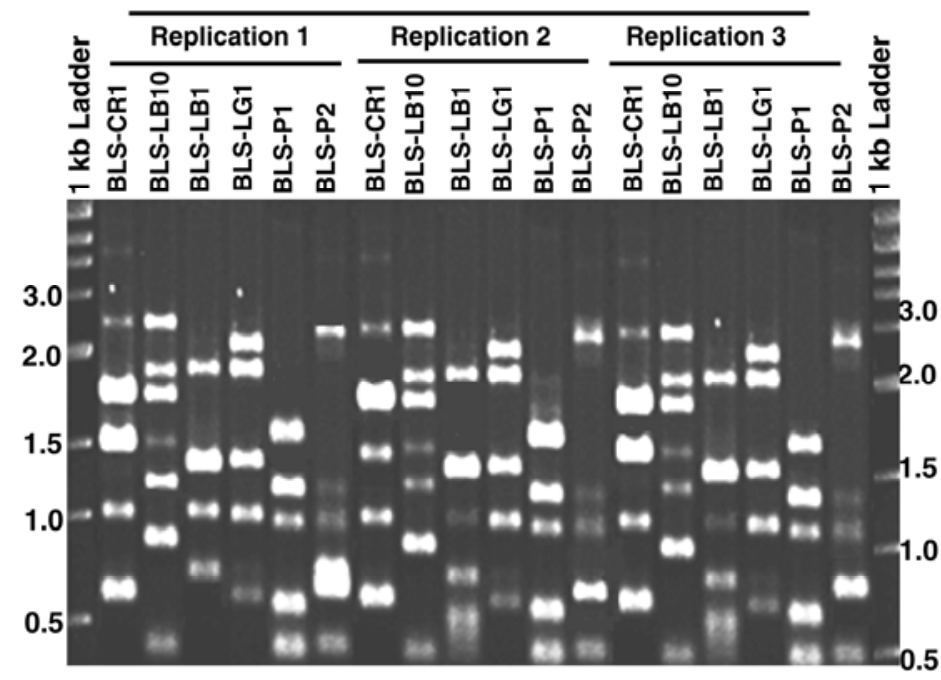

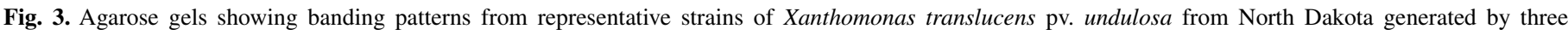

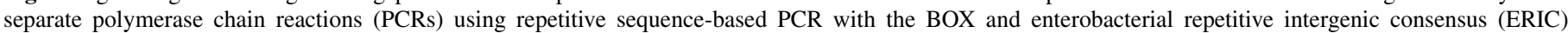

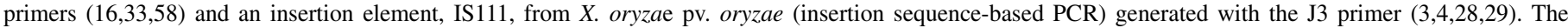

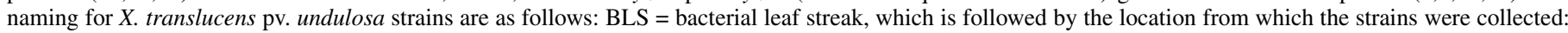

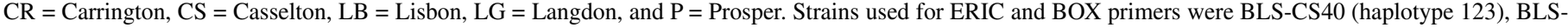

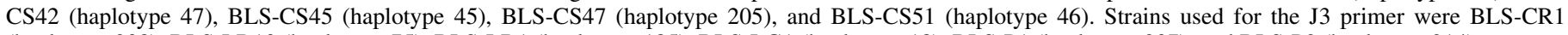
(haplotype 208), BLS-LB10 (haplotype 75), BLS-LB1 (haplotype 185), BLS-LG1 (haplotype 18), BLS-P1 (haplotype 207), and BLS-P2 (haplotype 214). 
wheat cultivars tested, no pathogenic races were previously found in this pathogen due to lack of significant wheat cultivar-bacterial strain interactions (39). Milus and Chalkly (39) further reported that no evidence for detecting races was found due to quantitative resistance to $X$. translucens pv. undulosa among 19 wheat cultivars tested. In the present study, a limited number of highly aggressiveness strains $(n=29)$ were evaluated on a set of 12 wheat cultivars $(2,18,35,40,55)$ and each strain was represented by a unique pathotype. The genetic mechanism causing this variability is unknown. In recent BLS outbreaks, winter, spring, and durum wheat cultivars presently grown in North Dakota were severely affected by BLS. We hypothesize that the susceptible wheat cultivars may provide favorable environments for primary inoculum production, which may undergo mutation and create pathogenic diversity in this pathogen.

Wheat 'Mochis', 'Pavon', 'PI 345476', 'PI 326301', 'PI 338387', and 'PI 351315' exhibited differential responses to several pathotypes of $X$. translucens pv. undulosa and could be good candidates for "differential cultivars". Two wheat cultivars ('Mochis' and 'Pavon') were highly resistant to X. translucens pv. undulosa in previous studies $(18,35)$; however, these cultivars were susceptible to several strains tested in this study. The presence of the highly aggressive pathotypes of $X$. translucens $\mathrm{pv}$. undulosa identified in the present study raises the question of whether or not these wheat cultivars ('Mochis' and 'Pavon') could be useful sources of resistance to multiple pathotypes of $X$. translucens pv. undulosa in wheat breeding programs. More importantly, the finding of significant wheat cultivar-bacterial strain interactions demonstrated in this study emphasizes the need to examine cultivar-strain interaction with more wheat cultivars. Investigating pathogenic variations with respect to diverse differential wheat cultivars and including additional strains from the Upper Midwest region of the United states of America will provide a clearer picture of pathogenic specialization in X. translucens pv. undulosa.

Previous studies on membrane protein analysis, fatty acid profiling, and 16S rDNA PCR-RFLP analysis have shown a high similarity among strains or pathovars of Xanthomonas $(44,47$, $61)$. The rDNA genes such as $16 \mathrm{~S}, 23 \mathrm{~S}$, and $5 \mathrm{~S}$ are highly conserved at the genus and species levels and, thus, are believed to be useful tools for grouping bacteria at taxonomic levels $(6,26)$. Comparison of sequence variation in $16 \mathrm{~S}$ rDNA region among 38 strains of $X$. translucens pv. undulosa from five locations in North Dakota, 8 reference strains of $X$. translucens pathovars, and 16 Xanthomonas type strains showed $>98.5 \%$ rDNA sequence identity and the maximum number of base differences of 26 . In addition, partial 16S rDNA sequences were identical among strains of $X$. translucens pv. undulosa studied, and our finding also supports previous studies $(23,41)$ that this technique was less effective in grouping the Xanthomonas strains at the pathovar level.

Limited information describing the genetic diversity in $X$. translucens pv. undulosa is available compared with such information for closely related pathovars of $X$. translucens. Using AFLP markers, Kolliker et al. (27) estimated the genetic diversity in $X$. translucens pv. graminis and reported significant effects based on the geographic location where samples were collected. Bragard et al. (10) analyzed the 68 strains of different pathovars of $X$. translucens, including $X$. translucens pv. undulosa, using pathological and molecular approaches. In addition, genetic diversity of different pathovars of $X$. campestris strains using probes containing $23 \mathrm{~S} \mathrm{rDNA}$ or $\mathrm{pBSF} 2$ resulted in clustering of strains for $X$. translucens pv. cerealis, $X$. translucens pv. hordei, and $X$. translucens pv. undulosa into different groups (11). RepPCR genomic fingerprint profiles were performed to compare 33 strains pathogenic to asparagus and $61 X$. translucens strains pathogenic to cereals and grasses (49). In addition, all 33 strains from asparagus were identified as X. translucens pv. undulosa, and induced water-soaking symptoms in susceptible wheat 'Florida 302' (49). In the present study, we used rep-PCR with ERIC and BOXAIR primers $(16,58)$ and IS-PCR with J3 primer $(3,4)$ to analyze five populations of $X$. translucens pv. undulosa sampled in North Dakota. These genotyping techniques revealed a high level of molecular polymorphisms among strains of $X$. translucens pv. undulosa. Similarly, a high genetic diversity has also been found in Ralstonia solanacearum in the Philippines (32) and in X. oryzae pv. oryzae in Nepal (3) and the Philippines (57) using rep-PCR and IS-PCR techniques. Although $X$. translucens pv. undulosa strains are highly diverse, no correlation between pathotypes and haplotypes was found.

This pathogen has been reported as seedborne $(21,50)$. The majority of the wheat seed lots used for planting in North Dakota originated from different sources such as foundation seed, breeder seed, and wheat germplasm exchange from other states or countries without seed certification for BLS. It is likely that these seed lots could be potential sources of bacterial transmission in the field. The combined rep-PCR and IS-PCR techniques used in this study allowed us to delineate strains of $X$. translucens pv. undulosa from North Dakota into distinct haplotypes. We hypothesize that these haplotypes could result in association with certain geographic locations in North Dakota, and the occurrence of severe BLS outbreaks in the region could be due to the presence of the same haplotype in different locations. The presence of unique haplotypes in certain locations in North Dakota indicates

TABLE 5. Estimates of population genetic differentiation $\left(G^{\prime \prime}{ }_{\mathrm{ST}}\right.$ ) (above diagonal) and genetic distance $(D)$ (below diagonal) among pairs of populations of Xanthomonas translucens pv. undulosa collected in North Dakota ${ }^{\mathrm{a}}$

\begin{tabular}{lccccc}
\hline Population & Carrington & Casselton & Lisbon & Langdon & Prosper \\
\hline Carrington & $\ldots$ & $0.146^{*}$ & $0.092^{*}$ & $0.218^{* *}$ & $0.011 \mathrm{~ns}$ \\
Casselton & 0.01 & $\ldots$ & $0.106^{*}$ & $0.014 \mathrm{~ns}$ & $0.101^{*}$ \\
Lisbon & 0.13 & 0.14 & $\ldots$ & $\ldots .030 \mathrm{~ns}$ \\
Langdon & 0.14 & 0.04 & 0.11 & 0.06 & $0.127^{*}$ \\
Prosper & 0.07 & 0.08 & 0.07 & $\ldots$
\end{tabular}

${ }^{\text {a }} G^{\prime \prime}$ ST $=$ corrected standardized fixation index $(24,36) ; *$ and * indicate significant at $P \leq 0.001$ and $\leq 0.05$, respectively; ns $=$ nonsignificant. Nei's unbiased $D$ was analyzed from clone-corrected data $(42,43)$.

TABLE 6. Analysis of molecular variance (AMOVA) among five populations of Xanthomonas translucens pv undulosa from North Dakota

\begin{tabular}{|c|c|c|c|c|c|}
\hline AMOVA $^{\mathrm{a}}$ & df & Estimated variance & Variation $(\%)$ & $F_{\mathrm{ST}}^{\mathrm{b}}$ & $P$ value \\
\hline Among five populations & 4 & 1.36 & 8.3 & 0.095 & 0.001 \\
\hline Individuals within population & 221 & 5.07 & 91.7 & $\ldots$ & $\ldots$ \\
\hline
\end{tabular}

a Genetic variation was grouped among populations and individuals within five populations from Carrington, Casselton, Lisbon, Langdon, and Prosper.

${ }^{\mathrm{b}} F_{\mathrm{ST}}=$ fixation index and the significance was determined by 1,000 random permutations. Clone-corrected data were used for AMOVA. 


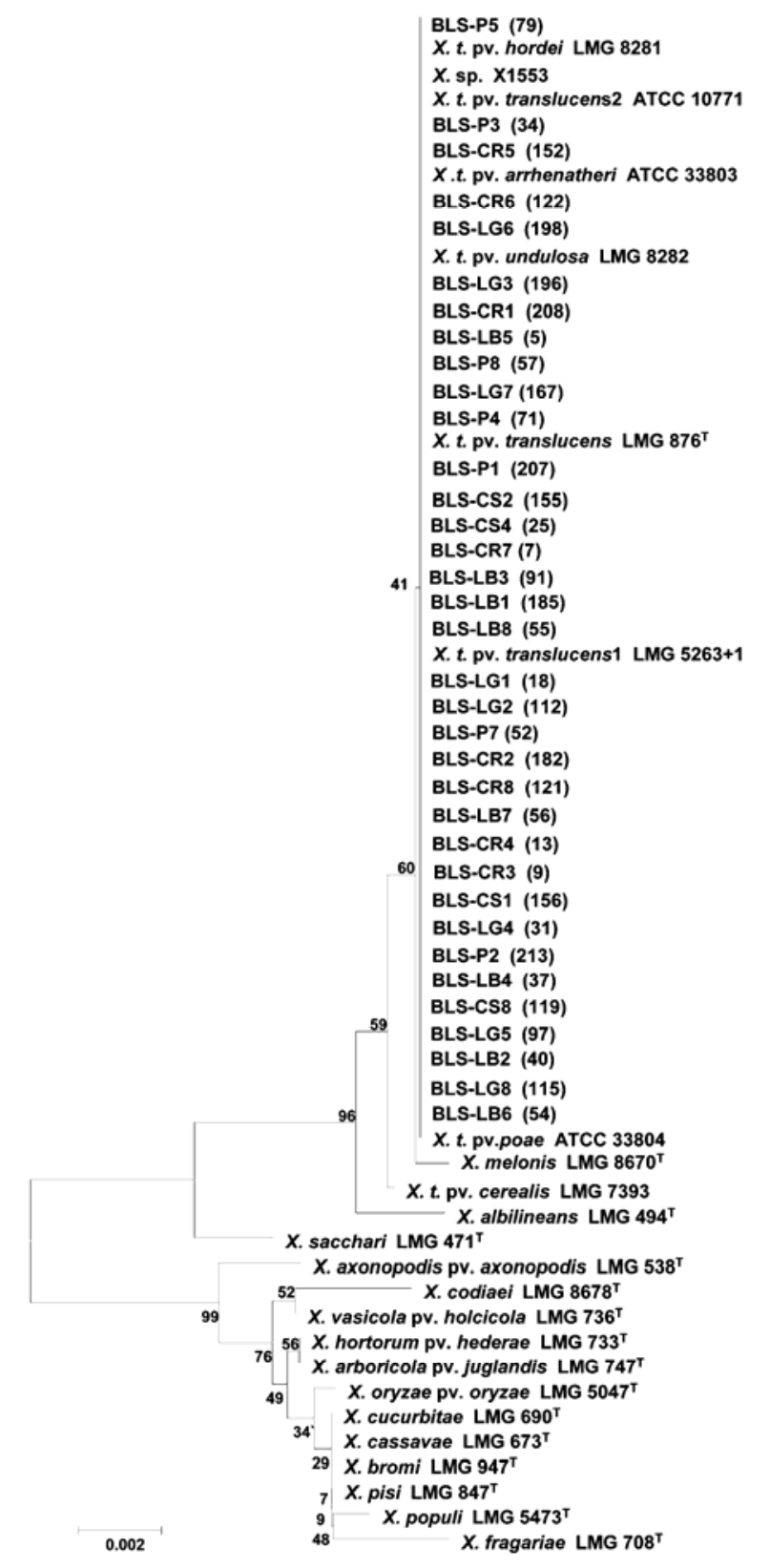

Fig. 4. Neighbor-joining trees based on $16 \mathrm{~S}$ rDNA sequence alignment of 35 Xanthomonas translucens pv. undulosa strains from five locations (Carrington, Casselton, Lisbon, Langdon, and Prosper) in North Dakota, other reference strains of $X$. translucens pathovars, and Xanthomonas pathovars (23). The naming for $X$. translucens pv. undulosa strains from North Dakota is as follows: BLS = bacterial leaf streak, which is followed by the location of its collection: $\mathrm{CR}=$ Carrington, $\mathrm{CS}=$ Casselton, $\mathrm{LB}=$ Lisbon, $\mathrm{LG}=$ Langdon, and $\mathrm{P}=$ Prosper. The eight $X$. translucens pathovars reference strains were $X$. translucens pv. poae (ATCC 33804), X. translucens pv. undulosa (LMG 8282), Xanthomonas sp. (X1553), X. translucens pv. arrhenatheri (ATCC 33803), X. translucens pv. cerealis (LMG 7393), X. translucens pv. translucens 1 (LMG $5263+1$ ), X. translucens pv. translucens 2 (ATCC 10771), and X. translucens pv. hordei (LMG 8281). The 16 Xanthomonas type strains were downloaded from the National Center for Biotechnology Information website (http:// www.ncbi.nlm.nih.gov/BLAST) with accession numbers in parentheses as follows: X. populi LMG 5743 (X95922), X. fragariae LMG 708 (X95920), X. hortorum pv. hederae LMG 733 (Y10759), X. arboricola pv. juglandis LMG 747 (Y10757), X. cassavae LMG 673 (Y10762), X. codiaei LMG 8678 (Y10765), X. bromi LMG 947 (Y10764), X. cucurbitae LMG 690 (Y10760), X. axonopodis pv. axonopodis LMG 538 (X95919), X. oryzae pv. oryzae LMG 5047 (X95921), X. vasicola pv. holcicola LMG 736 (Y10755), X. pisi LMG 847 (Y10758), X. melonis LMG 8670 (Y10756), X. translucens pv. translucens LMG 876 (X99299), X. sacchari LMG 471 (Y10766), and X. albilineans LMG 494 (X95918). Numbers on branches refer to bootstrap values (based on 1,000 replicates). Scale bar represents 0.002 nucleotide changes. the possibility of introducing new strains via short-distance migration from neighboring states or via long-distance introduction from wheat seed from other states or countries. Thus, one possible reason for significant differentiation of $X$. translucens $\mathrm{pv}$. undulosa populations in some locations also could be the development of different haplotypes propagating as primary inoculum sources from infected seed or other sources.

We observed significant $L D$ for $X$. translucens pv. undulosa populations from five locations in North Dakota analyzed. Similar findings also were reported when the haploid fungus Phaeosphaeria nodorum (causal agent of Stagonospora nodorum blotch of wheat) populations from spring wheat in North Dakota were analyzed using microsatellite markers (1). The reason for the significant disequilibrium in $X$. translucens pv. undulosa populations is unknown. However, several factors such as migration of individuals, sampling strategies, and lumping of strains from different locations may be responsible. Although X. translucens pv. undulosa populations appeared to be highly diverse, one possible explanation for observed significant $L D$ is the low level of horizontal gene transfer and recombination which probably occurs within fields.

In conclusion, the pathological and molecular tools used in this study offer a reliable approach for analyzing genetic diversity of strains of $X$. translucens pv. undulosa associated with the recent BLS outbreaks at a local or regional level in North Dakota. Although some winter wheat cultivars appeared to be resistant to $X$. translucens pv. undulosa (2), the high genetic diversity in $X$. translucens pv. undulosa strains found in this study could influence the durability and effectiveness of resistances in different geographic areas when widely deployed. Future studies are necessary to collect additional bacterial strains across a broader geographic scale to investigate pathogenic variability and population genetic structure, and to determine the usefulness of specific strains for identifying new sources of resistance to $X$. translucens pv. undulosa. A fundamental knowledge of the interaction between wheat cultivars and bacterial strains should aid in the breeding of commercially acceptable wheat cultivars with durable resistance to $X$. translucens pv. undulosa. The draft sequenced genome of $X$. translucens pv. undulosa strains is available. The development of PCR-based diagnostic markers for tracking of the pathogen in seed lots and identifying virulence factors such as the transcription activator-like effectors involved in pathogenesis are in progress.

\section{ACKNOWLEDGMENTS}

We thank the Wheat Research and Promotion Council, Minnesota, and United States Department of Agriculture-Agricultural Research Service specific cooperative agreement 58-5366-0-133 for financial support for this project;. D. Norman and C. Bragard for providing DNA and reference strains; and J. Patel and D. Soni for their assistance.

\section{LITERATURE CITED}

1. Adhikari, T. B., Ali, S., Burlakoti, R. R., Singh, P. K., Mergoum, M., and Goodwin, S. B. 2008. Genetic structure of Phaeosphaeria nodorum populations in the North-Central and Midwestern United States. Phytopathology 98:101-107.

2. Adhikari, T. B., Hansen, J. M., Gurung, S., and Bonman, J. M. 2011. Identification of new sources of resistance in winter wheat to multiple strains of Xanthomonas translucens pv. undulosa. Plant Dis.95:582-588.

3. Adhikari, T. B., Mew, T. W., and Leach, J. E. 1999. Genotypic and pathotypic diversity in Xanthomonas oryzae pv. oryzae in Nepal. Phytopathology 89:687-694.

4. Adhikari, T., Vera Cruz, C. M., Mew, T. W., and Leach, J. E. 1999. Identification of Xanthomonas oryzae pv. oryzae by insertion sequencebased polymerase chain reaction (IS-PCR). Int. Rice Res. Notes 24:23-24.

5. Agapow, P. M., and Burt, A. 2001. Indices of multilocus linkage disequilibrium. Mol. Ecol. Notes 1:101-102.

6. Barak, J. D., and Gilbertson, R. L. 2003. Genetic Diversity of Xanthomonas campestris pv. vitians, the causal agent of bacterial leafspot of 
lettuce. Phytopathology 93:1596-1603.

7. Berthier, Y., Verdier, V., Guesdon, J., Chevrier, D., Denis, J., Decoux, G., and Lemattre, M. 1993. Characterization of Xanthomonas campestris pathovars by rRNA gene restriction patterns. Appl. Environ. Microbiol. 59:851-859.

8. Boosalis, M. G. 1952. Epidemiology of Xanthomonas translucens (J. J. and R.) Dowson on cereals and grasses. Phytopathology 42:387-395.

9. Bradbury, J. F. 1986. Guide to Plant Pathogenic Bacteria. Mycological Institute, CAB International, Farnham House, Slough, UK.

10. Bragard, C., Singer, E., Alizadeh, A., Vauterin, L., Maraite, H., and Swings, J. 1997. Xanthomonas translucens from small grains: Diversity and phytopathological relevance. Phytopathology 87:1111-1117.

11. Bragard, C., Verdier, V., and Maraite, H. 1995. Genetic diversity among Xanthomonas campestris strains pathogenic for small grains. Appl. Environ. Microbiol. 63:1020-1026.

12. Bragard, C., and Verhoyen, M. 1993. Monoclonal antibodies specific for Xanthomonas campestris strains pathogenic to wheat and other small grain, in comparison with polyclonal antosera. J. Phytopathol. 139:217228.

13. Brunner, E., and Puri, M. L. 2001. Nonparametric methods in factorial designs. Stat. Pap. 42:1-52.

14. Bull, C. T., De Boer, S. H., Denny, T. P., Firrao, G., Fischer-Le Saux, M., Saddler, G. S., Scortichini, M., Stead., D. E., and Takikawa, Y. 2010. Comprehensive list of names of plant pathogenic bacteria, 1980-2007. J Plant Pathol. 92:551-592.

15. Cunfer, B. M., and Scolari, B. L.1982. Xanthomonas campestris pv. translucens on triticale and other small grains. Phytopathology 72:683686.

16. de Bruijn, F. J. 1992. Use of repetitive (repetitive extragenic element and enterobacterial repetitive intergenic consensus) sequences and the polymerase chain reaction to fingerprint the genomes of Rhizobium meliloti isolates and other soil bacteria. Appl. Environ. Microbiol. 58:2180-2187.

17. Duveiller, E., Bragard, C., Rudolph, K., and Fucikovsky, L. 1997. General concepts and methods for the identification of pathogenic bacteria of wheat. In: The Bacterial Diseases of Wheat: Concepts and Methods of Disease Management. E. Duveiller, L. Fucikovsky, and K. Rudolph, eds. CIMMYT, Mexico, D.F.

18. Duveiller, E., Ginkel, M. V., and Thijissen, M. 1993. Genetic analysis of resistance to bacterial leaf streak caused by Xanthomonas campestris pv. undulosa in bread wheat. Euphytica 66:35-43.

19. Excoffier, L., Laval, G., and Schneider, S. 2005. Arlequin (version 3.0): An integrated software package for population genetics data analysis. Evol. Bioinf. 1:47-50.

20. Excoffier L., Smouse P. E., and Quattro J. M. 1992. Analysis of molecular variance inferred from metric distances among DNA haplotypes: Application to human mitochondrial DNA restriction data. Genetics131:479491.

21. Forster, R. L., and Schaad, N. W. 1985. Evaluation of seed treatments for eradication of Xanthomonas campestris pv. translucens from wheat seed. (Abstr.) Phytopathology 75:1385.

22. Forster, R. L., and Schaad, N. W. 1988. Control of black chaff of wheat with seed treatment and a foundation seed health program. Plant Dis. 72:935-938.

23. Hauben, L., Vauterin, L., Swings, J., and Moore, E. R. B. 1997. Comparison of 16S ribosomal DNA sequences of all Xanthomonas species. Int. J. Syst. Bacteriol. 47:328-335.

24. Hedrick, P. 2005. A standardized genetic differentiation measure. Evolution 59:1633-1638

25. Heuer, H., Krsek, M., Baker, P., Smalla, K., and Wellington, E. M. H.1997. Analysis of actinomycete communities by specific amplification of genes encoding 16S rRNA and gel-electrophoretic separation in denaturing gradients. Appl. Environ. Microbiol. 63:3233-3241.

26. Jensen, M. A., Webster, J. A., and Straus, N. 1993. Rapid identification of bacteria on the basis of polymerase chain reaction-amplified ribosomal DNA spacer polymorphisms. Appl. Environ. Microbiol. 59:945-952.

27. Kölliker, R., Krähenbühl, R., Schubiger, F. X., and Widmer, F. 2006. Genetic diversity and pathogenicity of the grass pathogen Xanthomonas translucens pv. graminis. System. Appl. Microbiol. 29:109-119.

28. Leach, J. E., Rhoads, M. L., Vera Cruz, C. M., White, F. F., Mew, T. W., and Leung, H. 1992. Assessment of genetic diversity and population structure of Xanthomonas oryzae pv. oryzae with a repetitive DNA element. Appl. Environ. Microbiol. 58:2188-2195.

29. Leach, J. E., White, F. F., Rhoads, M. L., and Leung, H. 1990. A repetitive DNA sequence differentiates Xanthomonas campestris pv. oryzae from other pathovars of $X$. campestris. Mol. Plant-Microbe Interact. 3:238-246.

30. Leben, C. 1981. How plant-pathogenic bacteria survive. Plant Dis. 65:633-637.

31. Leung, H., Nelson, R. J., and Leach, J. E. 1993. Population structure of plant pathogenic fungi and bacteria. Adv. Plant Pathol. 10:157-205.

32. Lewis Ivey, M. L., McSpadden Gardener, B. B., Opina, N., and Miller, S.
A. 2007. Diversity of Ralstonia solanacearum infecting eggplant in the Philippines. Phytopathology 97:1467-1475.

33. Louws, F. J., Fulbright, D. W., Stephens, C. T., and de Bruijn, F. J. 1994 Specific genomic fingerprints of phytopathogenic Xanthomonas and Pseudomonas pathovars and strains generated with repetitive sequences and PCR. Appl. Environ. Microbiol. 60:2286-2295.

34. Louws, F. J., Fulbright, D. W., Stephens, C. T., and de Bruijn, F. J. 1995. Differentiation of genomic structure by rep-PCR fingerprinting to rapidly classify Xanthomonas campestris pv. vesicatoria. Phytopathology 85:528536.

35. Maraite, H., Bragard, C., and Duveiller, E. 2007. The status of resistance to bacterial diseases of wheat. Pages 37-49 in: Wheat Production in Stressed Environments. H. T. Buck., J. E. Nisi., and N. Salomon, eds. Springer, New York.

36. Meirmans, P. G., and Hedrick, P. W. 2011. Assessing population structure: $F_{\mathrm{ST}}$ and related measures. Mol. Ecol. Resour. 11:5-18.

37. Mellana, V. J., and Cooksey, D. A. 1988. Development of host range mutants of Xanthomonas campestris pv. translucens. Appl. Environ. Microbiol. 54:884-889.

38. Mergoum, M., Frohberg, R. C., and Stack, R. W. 2007. Breeding hard red spring wheat for Fusarium head blight resistance, successes and challenges. Pages 161-167 in: Wheat Production in Stressed Environments, vol. 12. H. T. Buck, J. E. Nisi, and N. Salomon, eds. Springer, Dordrecht, The Netherlands.

39. Milus, E. A., and Chalkly, D. B. 1994. Virulence of Xanthomonas campestris pv. translucens on selected wheat cultivars. Plant Dis. 78:612-615.

40. Milus, E. A., and Mirlohi, A. F. 1994. Use of disease reactions to identify resistance in wheat to bacterial streak. Plant Dis. 78:157-161.

41. Moore, E. R. B., Kruger, A. S., Hauben, L., Seal, S. E., Baere, R. D., Wachter, R. D., Timmis, K. N., and Swings, J. 1997. 16S rRNA gene sequence analyses and inter- and intrageneric relationships of Xanthomonas species and Stenotrophomonas maltophilia. FEMS Microbiol. Lett. 151:145-153.

42. Nei, M. 1973. Analysis of gene diversity in subdivided populations. Proc. Natl. Acad. Sci. USA 70:3321-3323.

43. Nei, M. 1978. Estimation of average heterogygosity and genetic distance from a small number of individuals. Genetics 89:583-590.

44. Nesme, X., Vaneechoutte, M., Orso, S., Hoste, B., and Swings, J. 1995. Diversity and genetic relatedness within genera Xanthomonas and Stenotrophomonas using restriction-endonuclease site differences of PCRamplified 16S ribosomal-RNA gene. Syst. Appl. Microbiol. 18:127-135.

45. Norman, D. J., Chase, A. R., Stall, R. E., and Jones, J. B. 1999. Heterogeneity of Xanthomonas campestris pv. hederae strains from araliaceous hosts. Phytopathology 89:646-652.

46. Peakall, R., and Smouse, P. E. 2006. GENALEX 6: Genetic analysis in Excel. Population genetic software for teaching and research. Mol. Ecol. Notes 6:288-295.

47. Ojanen, T., Helander, I. M., Haahtela, K., Korhonen, T. K, and Laakso, T. 1993. Outer-membrane proteins and lipopolysaccharides in pathovars of Xanthomonas campestris. Appl. Environ. Microbiol. 59:4143-4151.

48. Ou, S. H. 1985. Rice Diseases. Commonwealth Mycological Institute, Kew, Surrey, UK.

49. Rademaker, J. L. W., Norman, D. J., Forster, R. L., Louws, F. J., Schultz, M. H., and de Bruijn, F. J. 2006. Classification and identification of Xanthomonas translucens isolates, including those pathogenic to ornamental asparagus. Phytopathology 96:876-884.

50. Sands, D. C., Mizrak, G., Hall, V. N., Kim, H. K., Bockelman, H. E., and Golden, M. J. 1986. Seed transmitted bacterial disease of cereals: Epidemiology and control. Arab. J. Plant Prot. 4:125-127.

51. Schaad, N. W., Jones, J. B., and Lacy, G. H. 2001. Xanthomonas. In: Laboratory Guide for Identification of Plant-Pathogenic Bacteria, 3rd ed. N. W. Schaad, J. B. Jones, and W. Chun, eds. American Phytopathological Society Press, St. Paul, MN.

52. Shah, D. A., and Madden, L. V. 2004. Nonparametric analysis of ordinal data in designed factorial experiments. Phytopathology 94:33-43.

53. Smith, E. F., Jones, L. R., and Reddy, C. S. 1919. The black chaff of wheat. Science 50:48

54. Stead, D. E. 1989. Grouping of Xanthomonas campestris pathovars of cereals and grasses by fatty acid profiling. Bull. OEPP/EPPO Bull. 19:5768.

55. Tillman, B. L., Harrison, S. A., Clark, C. A., Milus, E. A., and Russin, J. S. 1996. Evaluation of bread wheat germplasm for resistance to bacterial streak. Crop Sci. 36:1063-1068.

56. Tubajika, K. M., Tillman, B. L., Russin, J. S., Clark, C. A., and Harrison, S. A. 1998. Relationship between flag leaf symptoms caused by Xanthomonas translucens pv. translucens and subsequent seed transmission in wheat. Plant Dis. 82:1341-1344.

57. Vera Cruz, C. M., Ardales, E. Y., Skinner, D. Z., Talag, J., Nelson, R. J., Louws, F. J., Leung, H., Mew, T. W., and Leach, J. E. 1996. Measurement of haplotypic variation in Xanthomonas oryzae pv. oryzae within a single 
field by rep-PCR and RFLP analyses. Phytopathology 86:1352-1359.

58. Versalovic, J., Koeuth, T., and Lupski, J. R. 1991. Distribution of repetitive DNA sequences in eubacteria and application to fingerprinting of bacterial genomes. Nucleic Acids Res. 19:6823-6831.

59. Wallin, J. R. 1946. Seed and seedling infection of barley, brome grass, and wheat by Xanthomonas translucens var. cerealis. Phytopathology 36:446-457.

60. Wiese, M. V. 1987. Compendium of Wheat Diseases, 2nd ed. American
Phytopathological Society, St. Paul, MN.

61. Yang, P., Vauterin, L., Vancanneyt, M., Swings, J., and Kersters, K. 1993. Application of fatty acid methyl esters for the taxonomic analysis of the genus Xanthomonas. Syst. Appl. Microbiol. 16:47-71.

62. Yeh, F. C., Yang, R. C., Boyle, T. B. J., Ye, Z. H., and Mao, J. X. 1997. POPGENE, the User Friendly Shareware for Population Genetic Analysis. Molecular Biology and Biotechnology Center, University of Alberta, Canada. 